\title{
Measurement of Phenotype Characteristics of Sasak Ducks: Indian Runner Ducks of Lombok Island Indonesia
}

\author{
Mohammad Hasil Tamzil and Budi Indarsih \\ Laboratory of Poultry Production, Faculty of Animal Science, University of Mataram \\ Jl. Majapahit No. 62 Mataram. Lombok, West Nusa Tenggara, Indonesia, 83125 \\ Corresponding author email: emhatamsil@yahoo.com
}

\begin{abstract}
This study was designed to determine the phenotype characteristics of Sasak ducks in Lombok Island. The study used 64 Sasak ducks at production stage which were kept intensively by small holder farmers. Observations on the characteristics of the feather color were carried out directly on each animal. The data observed were feather colors, beak color, and the color of the foot and shank, while the data on the size of the body that was observed were body weight, beak length, neck length, back length, breast circumference, back length, thigh length, shank length, and the distance between the two pubic bones. The data obtained were tabulated and analyzed descriptively. The study concluded that the characteristic of the color of feathers in Sasak ducks were dominated by Roman color $(50.13 \%)$, followed by Tanak color $(21.87 \%)$, Tongkak color (15.63\%), Rombak color (6.25\%), and Cemaning color (3.12\%). Sasak ducks with medium size were observed to have a relatively long beak, medium-long neck, short back, broad and deep chest, medium height, and the distance between the two pubic bones was quite wide. These characteristics indicate that Sasak ducks are the type of superior Indian Runner having better production ability compared to the other types of Indian Runner duck.
\end{abstract}

Key words: Sasak ducks, feather color, body size, egg production

Abstrak. Penelitian ini bertujuan untuk mengetahui karaktristik warna bulu dan ukuran tubuh itik Sasak. Penelitian menggunakan 64 ekor itik Sasak umur produksi yang dipelihara masyarakat secara intensif. Pengamatan pada karakteristik warna bulu dilakukan secara langsung pada setiap individu ternak. Data yang diamati adalah warna bulu, warna paruh, warna kaki dan betis, sedangkan data ukuran tubuh yang diamati adalah bobot badan, panjang paruh, panjang leher, panjang punggung, lingkar dada, panjang betis, panjang paha, panjang betis, dan jarak antara 2 tulang pubis. Data yang diperoleh ditabulasi dan dianalisis secara deskriptif. Hasil penelitian menyimpulkan bahwa karakter warna bulu itik Sasak didominasi oleh warna bulu Roman (50.13\%), kemudian diikuti oleh warna bulu Tanak (21,87\%), bulu Tongkak (15.63\%), bulu Rombak(6,25\%), dan warna Cemaning (3,12\%). Itik Sasak berukuran sedang dengan paruh relatif panjang, panjang leher sedang, punggung pendek, dada lebar dan dalam, tinggi sedang serta jarak antara dua tulang pubis tergolong lebar. Itik Sasak tergolong itik Indian Runner unggul dengan kemampuan produksi yang lebih baik dibandingkan dengan itik Indian Runner yang lain.

Kata kunci: itik Sasak, warna bulu, ukuran tubuh, produksi telur

\section{Introduction}

Indonesia has an extremely high natural diversity of tropical plants and animals. The diversity is marked by many types of laying ducks which spread from Sumatra, Java, Bali, West Nusa Tenggara to Kalimantan. Indonesian ducks belong to the Indian Runner and it is thought that their origin is India (Indian Runner means fast runner ducks from India) (Batty, 1985). Ducks that belong to the Indian Runner are Tegal ducks, Magelang ducks, Mojosari ducks, Cihateup ducks, Damiaking ducks, Cirebon ducks, Bali ducks, Alabio ducks, Turi ducks, Kerinci ducks, Pegagan ducks, and Sasak ducks (Tamzil, 2017). The main purpose of duck rearing in Indonesia is for producing eggs for human consumption.

Most types of Indian Runner are known to have characteristics of phenotype and genotype. Each type has its own characteristics so that it can be distinguished from the other types. The differences is due to human intervention to develop the duck for a specific purpose, as well as time gap between the domestication and their development (Batty, 1985; Hetzel, 1986; Tamzil, 2017). During the 
process of development, a non-structured outcrossing with a high intensity is occurred in the population that causes some variations in phenotypes even though originated from the same ancestor (Suparyanto, 2003).

Lombok Island is one of the development areas of duck farming. There are various types of ducks that were raised by the communities. However, in some places, there are still breeders who are loyal to Lombok original local ducks (Sasak ducks) (Tamzil, 2017). The characteristics of phenotype and genotype of these local ducks have not been identified. Therefore, this study was aimed to identify characteristics of the original genetic resources of Lombok Island as an initial data collection in efforts to develop genetic resources as one of poultries producing eggs for human consumption.

\section{Materials and Methods}

The data of the observed phenotype characteristics were feather color, beak color, shank color, body weight, and beak length, neck length, breast circumference, back length, thigh length, shank length, and the distance between the two pubic bones. Observations on the feather color characteristic, the body weight, and other duck, body parts were carried out on 62 Sasak Ducks at production stage (laying phase) kept by small holder farmers intensively. The data on the production performance (sexual maturity, egg production ability, the peak of egg production, and culling age) were collected through interview with the farmers. Data on egg weight were collected by directly weighing egg laid on the day of observation while at the same time observing the eggshell color. The frequency of feather color data was calculated using Stanfield formula (1983), while the data on the body size and the egg production performance were tabulated and analyzed descriptively.

\section{Results and Discussion}

The results of observation showed that the feathers of Sasak ducks were in the order of Roman (Figure 1), Rombak (Figure 2), Tanak (Figure 3), Tongkak (Figure 4), and Cemaning (Figure 5). The frequency of each color of the feathers is presented in Table 1.

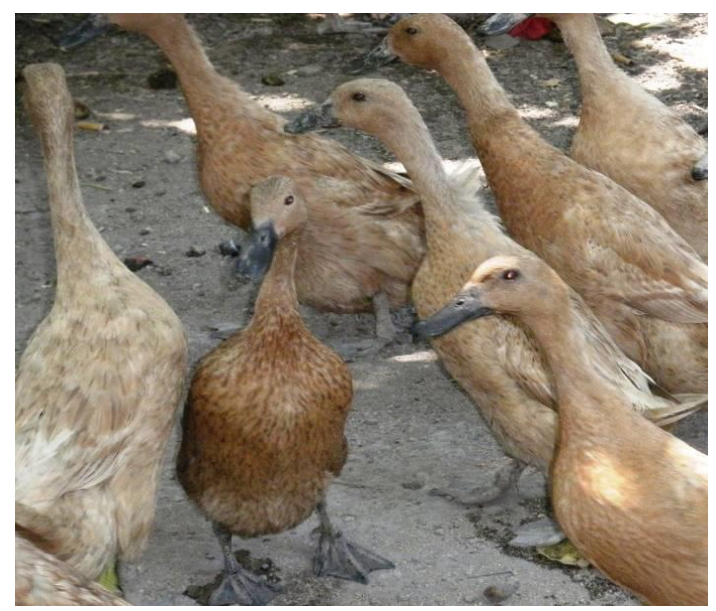

Figure 1. Roman color

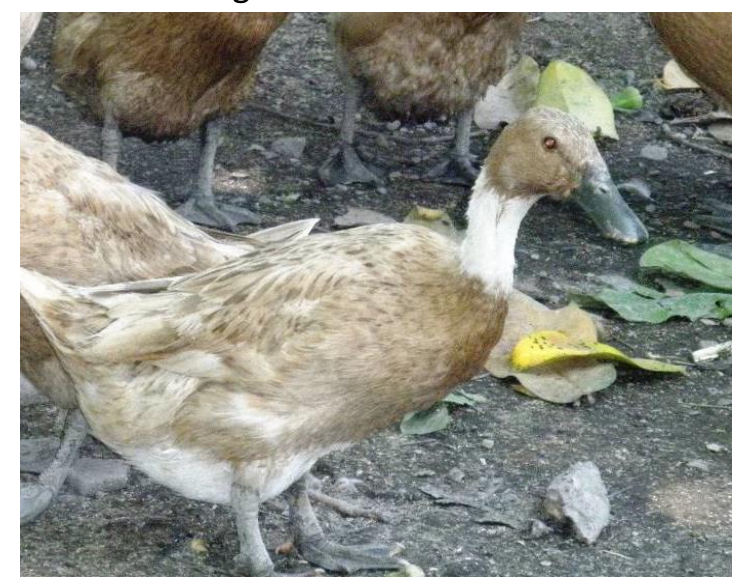

Figure 2. Rombak color

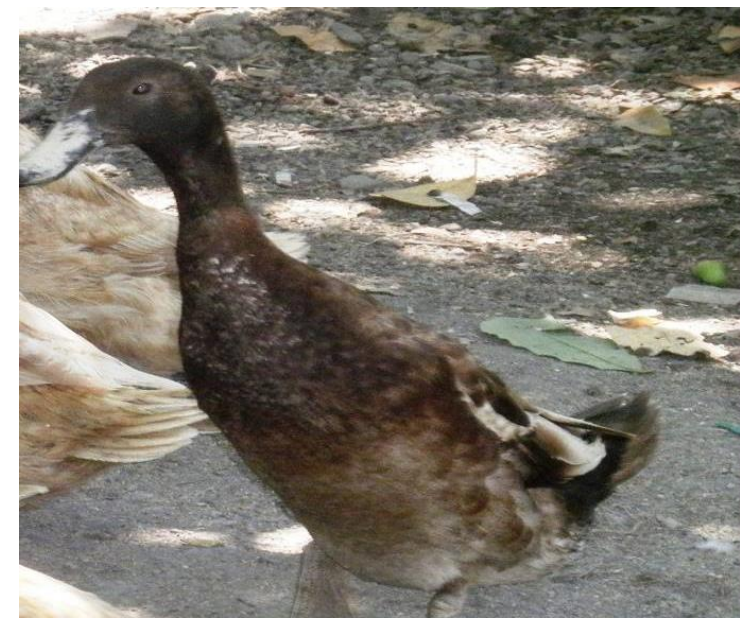

Figure 3. Tanak color 


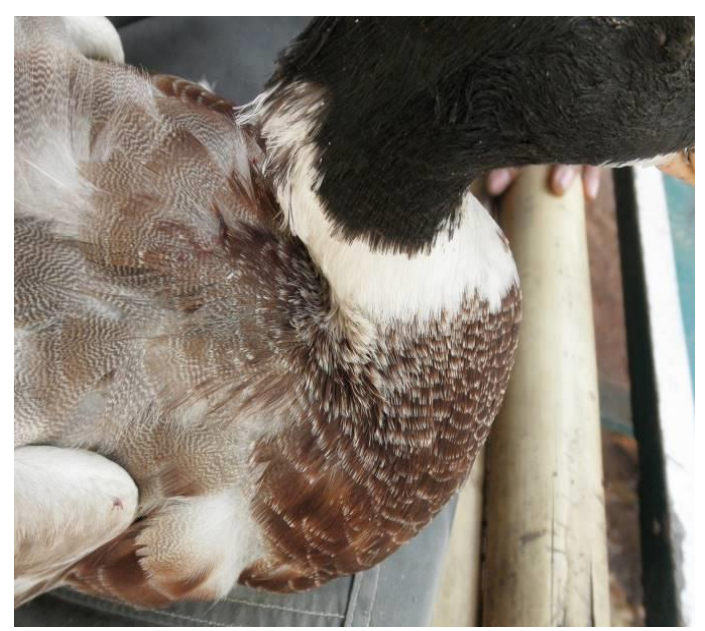

Figure 4. Tongkak color

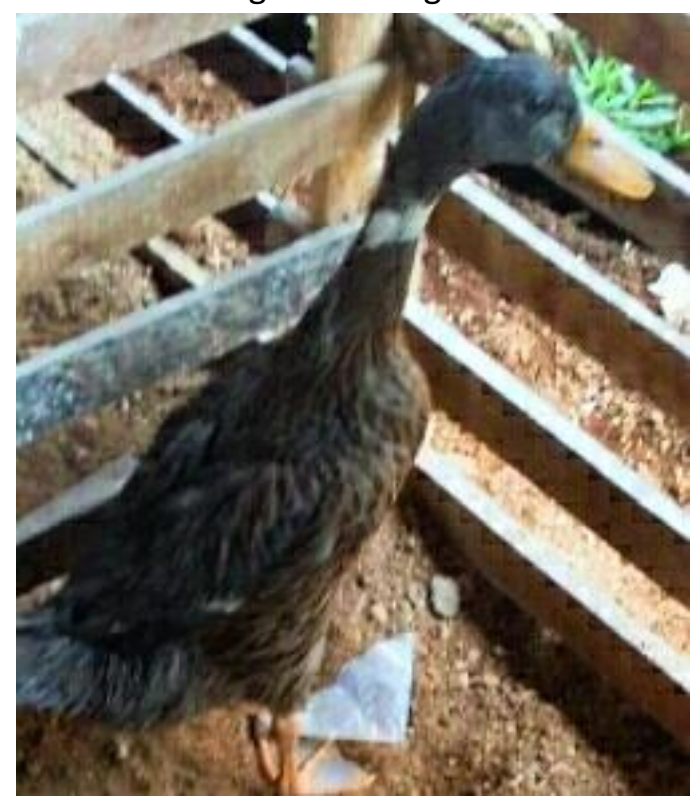

Figure 5. Cemaning color

Table 1. The frequency of feather color of Sasak ducks during data collection $(n=64)$

\begin{tabular}{lc}
\hline Feather color & Frequency (\%) \\
\hline Roman & 53.13 \\
Tanak & 21.87 \\
Tongkak (kalong) & 15.63 \\
Rombak & 6.25 \\
Cemaning & 3.12 \\
\hline
\end{tabular}

Roman word in Sasak language (Lombok) means dry straw, therefore feather having roman color is feather that resembles the color of dried rice straw. Specifications of ducks with Roman colors are 1) black beak; 2) light brown colored-head (called roman); 3) light brown colored-neck area and upper part of the back and lower body; 4) brown colored-central part of the wing feathers, with light brown on the primer feather; 5) feathers on the wing base are white.

Tanak feather is the way to call black colored ducks. The specifications of Tanak feather color of Sasak ducks are as follows: 1) Black head. For the male Sasak Duck, there are two types of black color of the head, (dark black and greeny black when exposed to sunlight). The green color is similar to the green head of Wild Mallard (green-headed wild ducks), the ancestors of the existing ducks (Batty, 1985). 2) Black beak; 3) In the Sasak male ducks, their upper necks are black, and then the color gradually changed into brighter colors up to the rear of the body. 4) Secondary feathers on the central part of the wing are black, while the color of the upper part is whitish and the color of the tip of the wing is faded color. 5) The colors of lower and front parts of the body are black. The black color is gradually getting brighter near the rear parts of the body. 6) The upper part of the body up to the tail is black.

Tongkak color is also called bat color. Sasak ducks are called bat color if there is white color circling the neck looking like a bat, while feather color of the body can be Roman or Tanak. Rombak color of Sasak ducks are given to the ducks having white feathers on some parts of their bodies, such as on the chest, the back, and other parts. Cemaning color is a name given to ducks having yellow beak and orange legs. Feathers on the head and neck are black, and there are tongkak (bats) shapes on the neck area. The color of feather in the hip area is brownish white heading to black. The bottom and top parts of the tail are black, while the left and right parts are white.

Data of color frequency on Table 1 show that the colors of feather in Sasak Ducks are dominated by roman color, followed by tanak color, tongkak color, rombak color, and lastly 
cemaning color. By observing the characteristic of feather color of Sasak ducks, it can be seen that there is a quite high color variation on Sasak ducks. The diversity of the feather color of Sasak ducks was lower than that of Tegal ducks that have up to nine color variations (Srigandono and Sarengat, 1990), but higher than that of Bali ducks' color with 3 colors including sumi, sumbian, and sinkep (Tamzil, 2017), and Mojosari ducks only have 2 colors (Sofiyana et al., 2003). Indian Runner ducks having the lowest color frequency are Magelang ducks (Mahfuz et al., 2005), Cihateup ducks (Dudi, 2007), Damikaking ducks (Sofiyana et al., 2003), Cirebon ducks (Setioko et al., 2005), Turi ducks (Yuwanta et al., 2000), Pegagan ducks (Sari et al., 2012), and Kerinci ducks (Supriyadi, 2011), which only has one color (uniform) each. The high diversity of feather colors of Sasak ducks provides a signal that Sasak duck belong to local ducks with genetic diversity and high population expansion. Mating between individuals still occurs randomly and openly (Noor, 2010), hence it still has a good genetic diversity. In one population are usually dozens of female ducks and a couple of male ducks. Thus, in the duck rearing in Lombok Island, mating occurs randomly, where, for instance, one male duck has an equal chance to mate with female ducks in their group.

In an attempt to get the data on body size characteristics of Sasak ducks, several parts of their body were measured. Results are shown in Table 2. The data in Table 2 also informs that the beak length of Sasak ducks is the same as that of Pengging Ducks (Wulandari et al., 2015) but longer than the beak of Tegal, Magelang, and Damiaking ducks (Sofiyana et al., 2003), Cihateup ducks (Dudi 2007), Cirebon ducks and Turi ducks (Setioko et al., 2005), Alabio ducks (Suryana, 2013; Suryana et al., 2011). Therefore, the length of this part can be used as a marker of phenotype of Sasak ducks. The beak length of Tegal, Magelang, Damiaking ducks are $5.66 \pm 0.13 \mathrm{~cm}, 6.17 \mathrm{~cm} \pm 0.34,5.63 \pm$
$0.44 \mathrm{~cm}$, respectively (Sofiyana et al., 2003), while the beak length of Pegging Duck is $7.20 \pm$ 1.41 (Wulandari et al., 2015), and the beak length of Albino Ducks is $5.69 \pm 0.45$ (Suryana, 2013; Suryana et al., 2011). On the other hand, the beak length of male and female Cehateup ducks is $6.54 \pm 0.32 \mathrm{~cm}$ and $6.30 \pm 0.10 \mathrm{~cm}$, respectively (Dudi, 2007), of Cirebon and Turi ducks are $5.55 \pm 0.30$ and $6.06 \pm 0.35 \mathrm{~cm}$, respectively (Setioko et al., 2005).

Table 2. Parts of the body measured $(n=64)$

\begin{tabular}{lcc}
\hline Body parts & Mean & $\begin{array}{c}\text { Standard } \\
\text { deviation }\end{array}$ \\
\hline Beak length $(\mathrm{cm})$ & 7.00 & 0.67 \\
Neck length $(\mathrm{cm})$ & 20.45 & 1.50 \\
Back length $(\mathrm{cm})$ & 20.77 & 1.93 \\
Breast size $(\mathrm{cm})$ & 29.23 & 1.77 \\
Thigh length & & \\
(cm) & 8.77 & 1.27 \\
Drumstick length & & \\
(cm) & 10.91 & 0.81 \\
Shank length (cm) & 6.09 & 0.87 \\
Distance of two & & \\
pubic bones (cm) & 3.83 & 1.27 \\
\hline
\end{tabular}

The average neck length of Sasak ducks in this study is $20.45 \pm 1.50 \mathrm{~cm}$, shorter than that of Alabio ducks, Tegal duck, Cihateup duck, Damiaking duck, and Cirebon ducks, but longer than that of Magelang ducks and Turi ducks. The neck length of Tegal, Cihateup, Damiaking, and Cirebon ducks are $21.81 \pm 1.29 \mathrm{~cm}$ (Sofiyana et al., 2003), $25.50 \pm 1.40$ (Dudi, 2007), $21.27 \pm 1.06 \mathrm{~cm}, 21.22 \pm 1.46 \mathrm{~cm}$ (Setioko et al., 2005) and 22,33 \pm 3.54 (Suryana, 2013; Suryana et al., 2011), while that of Magelang ducks is $17.08 \pm 1.54 \mathrm{~cm}$ (Sofiyana et al., 2003) and Turi ducks is $18.92 \pm 1.06 \mathrm{~cm}$ (Setioko et al., 2005). It can be concluded that Sasak ducks have necks with medium length sizes.

The data in Table 2 provides information that the back length of Sasak ducks (20.77 \pm 
$1.93 \mathrm{~cm}$ ) is similar to $20.86 \pm 1.26 \mathrm{~cm}$ in Tegal ducks, shorter than 22.44 \pm 2.4 in Alabio ducks (Suryana, 2013; Suryana et al., 2011), $25.95 \pm 1.87 \mathrm{~cm}$ in Magelang ducks, $23.14 \pm 1.87$ $\mathrm{cm}$ in Damiaking ducks (Sofiyana et al., 2003), $22.452 \pm 0.74 \mathrm{~cm}$ in Cirebon Ducks, and $22.64 \pm 1.01 \mathrm{~cm}$ in Turi ducks (Setioko et al., 2005). These data show that Sasak Ducks have relatively shorter back length than that of other Indian Runner duck types.

Data of the chest circumference of Sasak ducks are presented in Table 2 show that the chest circumference of Sasak ducks is similar to that of Damiaking ducks, but bigger than that of Tegal ducks, Magelang ducks, Cirebon ducks, and Turi ducks. Tegal ducks have $27.88 \pm 1.66 \mathrm{~cm}$ circumference (Sofiyana et al., 2003), while Damiaking ducks, Magelang ducks, Cirebon ducks, and Turi ducks are $29.57 \pm 1.54 \mathrm{~cm}$, $27.55 \pm 0.10 \mathrm{~cm}$ (Sofiyana et al., 2003), 28.19 \pm 1.7 $\mathrm{cm}$, and $28.48 \pm 1.81 \mathrm{~cm}$ (Setioko et al., 2005), respectively. It indicates that chest circumference of Sasak ducks is bigger than that of other Indian Runner duck types.

Data of drumstick length, thigh length, and shank length of Sasak ducks gathered in this study are $8.77 \pm 1.27 \mathrm{~cm}, 10.91 \pm 0.81 \mathrm{~cm}$, and $6.09 \pm 0.87 \mathrm{~cm}$, respectively (Table 2 ). The score is shorter than those of Tegal duck $(9.05 \pm 0.74$ $\mathrm{cm}, \quad 11.14 \pm 0.82 \mathrm{~cm}$, and $6.79 \pm 0.56 \mathrm{~cm}$, respectively), Magelang ducks $(9.65 \pm 0.62 \mathrm{~cm}$, $14.03 \pm 1.06 \mathrm{~cm}$, and $7.10 \pm 0.51 \mathrm{~cm})$, and Cirebon ducks $(7.99 \pm 0.67 \mathrm{~cm}, 11.74 \pm 0.57 \mathrm{~cm}$, and $6.55 \pm 0.50 \mathrm{~cm}$, respectively)(Setioko et al., 2005)., but longer than those of Damiaking ducks $(7.91 \pm 0.46 \mathrm{~cm}, 10.60 \pm 0.88 \mathrm{~cm}$, and $5.88 \pm 0.44 \mathrm{~cm}$, respectively) (Sofiyana et al., 2003) and Turi ducks. Therefore, the length of drumstick, thigh, and shank that reflects the duck's height belongs to medium size, and it can be concluded that the height of Sasak ducks is medium.

The data in Table 2 also inform that the stretch between the two pubic bones in Sasak ducks reaches $3.83 \pm 1.27 \mathrm{~cm}$ that is high compared with the size between the two pubic bones of other types of Indian Runner ducks. Average stretch between the two pubic bones of Tegal ducks is $3.05 \pm 0.16 \mathrm{~cm}, 3.0 \pm 0.12 \mathrm{~cm}$ in Magelang ducks and $3.01 \pm 0.17 \mathrm{~cm}$ in Damiaking ducks (Sofiyana et al., 2003). The distance between the two pubic bones can be utilized as an indicator of egg production level estimator (Hartono, 2006). Based on these data, it is strongly indicated that Sasak ducks are the type of superior laying ducks, and the unidentified potentials need to be studied in further detail.

Production performance of Sasak duck is presented in Table 3. The eggshell color of Sasak duck is the same as that of other types of Indian Runners, such as Tegal ducks (Tamzil, 2017), Mojosari ducks (Brahmantyo et al., 2003), Cirebon ducks (Setioko et al., 2005), Magelang ducks (Sofiana et al., 2003), Turi ducks (Yuwanta et al., 2000), Damiaking ducks (Sofiana et al., 2003), Cihateup ducks (Dudi, 2007), and Pitalah ducks (Kementan, 2011). The similarity of the color of eggshell is an indication that Sasak ducks is part of the Indian Runner family. Further studies on ducks' genetic distance is essential to foster this finding. The studies could use blood protein approach or molecular approach.

Table 3. Production performance of Sasak ducks

\begin{tabular}{ll}
\hline $\begin{array}{l}\text { Performance of } \\
\text { production }\end{array}$ & $\begin{array}{l}\text { Observation } \\
\text { result }\end{array}$ \\
\hline Body Weight & $1613.82 \mathrm{~g}$ \\
Eggshell color & $\begin{array}{l}\text { Greenish blue } \\
\text { Egg weight }\end{array}$ \\
$\begin{array}{l}\text { Age of sexual maturity } \\
\text { Time reached the peak of }\end{array}$ & 22 weeks \\
egg production & 34 weeks \\
Culling age & 2 years \\
\hline
\end{tabular}

Data of the egg weight, age of sexual maturity, and egg peak production of Sasak ducks show the same results as the previous studies using other types of Indian Runner. Age of sexual maturity of Mojosari ducks is 5.5 
months and the egg weight ranges from $60-70 \mathrm{~g}$ (Suparyanto, 2003). Tamzil et al. (1999) found that Cirebon ducks reaches their age of sexual maturity between 141.83-158.34 old days, with the weight of first eggs from 48.04 to $54.38 \mathrm{~g}$. Tegal ducks reach their age of sexual maturity between $148.44-153.05$ old days, and the egg weight is from 48.9 to $63.1 \mathrm{~g}$ (Hardjosworo, 1989). Other studies found that age of sexual maturity of Tegal ducks started showing when the ducks are 101 days old and culminates at 210 days old days, with the weight of eggs ranges from 62.7-70.2 g (Hetzel and Gunawan, 1984). The average age of sexual maturity in Alabio ducks is 24.27 weeks old, while Mojosari ducks is at the age of 24.5 old weeks, with the average weight of eggs respectively is around 56.9-53.69 g per egg (Ketaren et al., 2007).

When the culling age of this study is compared to that of other studies using Indian runner, it can be seen that Sasak duck belongs to superior Indian Runner duck type. Ketaren and Prasetiyo (2002) found that at 24 weeks old, egg production declined to $30 \%$, while egg production period of Sasak duck could last for 10 months.

The data in Table 2 provide information that body weight of Sasak ducks fall into the category of medium weight. Mean body weight of Sasak ducks (1613.82 $\pm 224.55 \mathrm{~g}$ ) is similar to that of Damiaking ducks from Serang Banten areas with mean body weight is about $1610 \pm$ 176 grams (Sofiyana et al., 2003), but higher than the weight of Tegal and Magelang ducks. The body weight of Tegal ducks is $1571 \pm 177 \mathrm{~g}$ and Magelang ducks is $1523 \pm 144 \mathrm{~g}$ (Sofiyana et al., 2003). However, when compared with Cihateup ducks weighing $2.7 \pm 0.05 \mathrm{~kg}$ (Dudi, 2007), Sasak ducks is lighter than that of Cihateup ducks.

\section{Conclusions}

The feather colors of Sasak ducks are dominated by Roman, followed by Tanak,
Rombak, Tongkak, and Cemaning. The body size of Sasak ducks is moderate with a relatively long beak, medium neck, short back, broad and deep chest, medium height, and the distance between the two pubic bones are quite wide. It is advisable to do research in various aspects of Sasak ducks in effort to enrich scientific studies as the basis for the development of local ducks in the future. Sasak ducks is the type of superior Indian Runner having high production ability which is better than that of other types of Indian Runner ducks.

\section{Acknowledgement}

Gratitude and appreciation go to PNBP Mataram University Funding 2014, also to Masdarni for his help during data collection, and to Prof. Wasmen Manalu, Ph.D., Professor at the Faculty of Veterinary Medicine, Bogor Agricultural University, for his willingness to read and correct this manuscript.

\section{References}

Batty, J. 1985. Domesticated duck and geese. $2^{\text {nd }}$ Ed. Fanciers Supliers Ltd., England.

Brahmantiyo B, LH, Prasetyo, AR Setioko and RH Mulyono. 2003. Pendugaan jarak genetik dan faktor peubah pembeda galur itik (Alabio, Bali, Khaki Campbell, Mojosari dan Pegagan) melalui analisis morfometrik. JITV 8(1): 1-7.

Dudi. 2007. Identifikasi sifat kuantitatif itik Cihateup sebagai sumber daya genetik unggas lokal. Jurnal Ilmu Ternak. 7(1): 39-42.

Hardjosworo PS. 1994. Upaya untuk Mencari Ciri Fisik Petelur Lokal Betina yang Baik. Lebar Rentang Pubis Itik Lokal Betina pada saat Masak Kelamin. Media Peternakan. P: 1-5.

Hartono. 2006. Pemanfaatan lebar regangan tulang pubis untuk menduga produktifitas itik Tegal. Temu Teknis Nasional Fungsional Pertanian. 306308.

Hetzel DJS and B Gunawan. 1984. Egg production of Indonesian native and crossbred ducks under intensive and extensive conditions. Tropical Animal Production. 9: 203-215. 
Hetzel DJS. 1986. Domestic Ducks: An Historical Perspectives. In: D.J. Farrell and P Stapliton (ed). Duck Production Science and World Practice. Pp: 1-5.

Kementan RI. 2011. Keputusan Mentri Pertanian Republik Indonesia, Nomor 2923/Kpts/ OT.140/6/2011. Tentang Penetapan Rumpun Itik Pitalah. Jakarta.

Ketaren PP and LH Prasetyo. 2007. Pengaruh pemberian pakan terbatas terhadap produktivitas itik silang Mojosari X Alabio (MA): Masa pertumbuhan sampai bertelur pertama. JITV 12(1): 10-15.

Ketaren PP and LH Prasetyo. 2002. Pengaruh pemberian pakan terbatas terhadap produksi itik silang Mojosari x Alabio: 2. Masa bertelur fase kedua umur 44-67 minggu. JITV 7(1): 38-45.

Mahfudz S, TA Kismiati, Sarjana. 2005. Fenotipik dari itik Magelang yang Produkstif. Seminar Nasional Teknologi Peternakan dan Veteriner: 779-785.

Noor RR. 2010. Genetika Ternak. Penebar Swadaya, Jakarta. P. 200

Sari ML, RR Noor, PS Hardjosworo, C Nisa. 2012. Kajian Karaktristik Biologis Itik Pegagan Sumatra Selatan. Jurnal Lahan Suboptimal. 1 (2): 170-176.

Setioko AR, S Sofiyana and D Sunandar. 2005. Identifikasi Sifat-sifat Kualitatif dan Ukuran Tubuh pada Itik Tegal, Itik Cirebon, dan Itik Turi. Proseding Seminar Nasional dan Veteriner. 786794.

Sofiyana S, AR Setiok and ME Yusnandar. 2003. Identifikasi Sifat-sifat Kualitatif dan Ukuran Tubuh pada Itik Tegal, Itik Magelang, dan Itik Damiaking. Lokakarya Nasional Teknologi dalam Mendukung Usaha Ternak Unggas Berdaya saing. 123-130.

Srigandono B and W Sarengat. 1990. Ternak itik beridentitas Jawa Tengah. Fakultas Peternakan Universitas Diponegoro Semarang. Dalam: Prosiding Temu Tugas Sub Sektor Peternakan,
Pengembangan Ternak Itik Di Jawa Tengah. Pp: 10-16.

Stanfield WD. 1983. Theory and Problems of Genetics. 2nd. Ed. Mc. Graw Hill Company Inc. New York.

Suryana. 2013. Pemanfaatan keragaman genetik untuk meningkatkan produktivitas itik Alabio. J. Litbang Pert. 32(2): 100-111

Suryana, R.R. Noor, P.S. Hardjosworo, dan L.H. Prasetyo. 2011. Karakteristik fenotipe itik alabio (Anas platyrhynchos Borneo) di Kalimantan Selatan. Buletin Plasma Nutfah 17(1): 61-67

Suparyanto A. 2003. Karakteristik itik Mojosari putih dan peluang pengembangan sebagai itik pedaging komersial. Wartazoa 13(4):143-150.

Supriyadi. 2011. Panduan Beternak Itik. Badan Penyuluhan dan Pengembangan Sumber Daya Pertanian, Kementerian Pertanian, Republik Indonesia. Jakarta.

Tamzil MH. 2017. Ilmu dan Teknologi Pengelolaan Plasma Nutfah Ternak Itik. Mataram University Press. Mataram.

Tamzil MH, PS Hardjosworo, DTH Sihombing and W Manalu. 1999. Pengaruh pembatasan pemberian pakan terhadap penundaan masak kelamin itik Lokal yang cenderung masak kelamin dini. Media Veteriner. Majalah IImu Kedokteran Veteriner Indonesia. Fakultas Kedokteran Hewan Institut Pertanian Bogor. 6(2): 5-9.

Wulandari D, Sumarno and TS Saraswati. 2015. Perbedaan Somatometri itik Tegal, itik Magelang, dan itik Pengging. BIOMA 17(2):94-101.

Yuwanta A, NK Zuprizal and Wardhani. 2000. Studi potensi genetik produksi dan reproduksi serta bahan pakan lokal pada itik Turi sebagai itik Petelur. Laporan Hasil penelitian Lembaga Penelitian Universitas Gadjah Mada, Yogyakarta. 